\title{
What makes for prize-winning television?
}

\author{
Abstract \\ We investigate the determinants of success in four international television awards \\ festivals between 1994 and 2012. We find that countries with larger markets and greater \\ expenditure on public broadcasting tend to win more awards, but that the degree of \\ concentration in the market for television and rates of penetration of pay-per-view \\ television are unrelated to success. These findings are consistent with general industrial \\ organisation literature on quality and market size, and with media policy literature on \\ public service broadcasting acting as a force for quality. However, we also find that \\ 'home countries' enjoy a strong advantage in these festivals, which is not consistent with \\ festival success acting as a pure proxy for television quality.
}

\section{What makes for prize-winning television?}

Whilst not quite as keen as the average American, Europeans still watch considerable amounts of television, and more than the global average for television viewers of 3 hours and 17 minutes. Whether in Romania (5 hours 30 minutes per day) or in Spain (4 hours 6 minutes), over a lifetime, most people will spend more time watching television than they do at work (Médiamétrie, 2012). Insofar as it is important that this time is 'well-spent', the quality of television matters. Little, however, is known about what determines quality and how it might be usefully affected by policy. Part of the difficulty with this policy question arises because 'quality' can be understood in a variety of ways (see, for example, McCabe and Akass, 2007). We sidestep this difficulty here by focusing on one indicator of quality: winning prizes at International Festivals. In particular, we examine, using the evidence of the last twenty years, what aspects of a country's television industry are associated with success at these festivals.

This is not to claim that there are no other important senses of quality. There are. However, prizes are both easily quantifiable and can broadly claim the authority of a peer judgement that has 
been found in the related industry of film to be associated with two other measures of quality. Thus, Oscar awards in films are correlated with box office receipts (which reflects the extent to which consumers value a film) and, albeit less strongly, with the more considered judgments that arise with the passage of time in larger communities of those who watch and make films (see Ginsburgh, 2003). Similar claims can be made for literary prizes (English, 2009). Literary prizes may also serve to highlight competing discourses of quality, and contrasting mechanisms for identifying it (Verboord (2011 and 2012). Our analysis of the conditions that produce quality television are intended as a further contribution to an understanding how 'quality' is discerned, attributed and delivered.

It is evident that different measures of quality and different means of attributing it will produce different results (Allen and Lincoln 2004; Verboord 2012). The awarding of prizes at festivals is but one example of this process. But because it is susceptible to systematic comparative analysis over time and space, it allows us to identify the structural factors that affect the attribution of 'quality' in the terms recognised by television festivals. This, we believe, constitutes a valuable contribution to understanding how content of a particular, prize-winning kind is produced by a particular market form.

In the next section, we introduce the four international festivals we discuss and the data on prizes that they generate. In section 3, we highlight the important features of a television industry that theory (and related empirical evidence) suggests might be important determinants of quality. For example, the size of the domestic market, the extent of competition and the character of the public service broadcasting tradition in a country might all plausibly affect the quality of that country's programming and its chances of winning prizes. Because it is often argued that that there are distinct types of 'media systems' that function differently (see Hallin and Mancini, 2004 and 2012) and between which the influence of competition on quality may vary, we focus on a group of (European) countries that offer some variety along these potential dimensions of influence but which nevertheless all belong to a broadly recognisable system that mixes significant public service 
broadcasting with the interests of commercialism. We exclude the US because it most clearly belongs over this period to a system where the public service tradition is marginal and commercial interests dominate. This strategy enables us to test whether systems are indeed qualitatively different in this sense by examining whether the determinants of European success when applied to the US industry predicts their performance (see Section 6).

Section 4 gives the details of our estimation method and section 5 gives the results. We find that both domestic market size and public broadcasting expenditure (but not regulatory regime) affect the chances of winning prizes, with the former having the greater effect. We did not find, however, that market concentration or the penetration of pay-per-view television had a significant effect on the propensity to win prizes. There is in most, but not all, cases, a 'home advantage' for the country that hosts the festival. We also find that the model when applied to the US provides plausible predictions for their success in these festivals.

\section{The festivals}

Our four festivals - the Prix Italia, the Montreux festival, the Monte Carlo festival, and the International Emmies - have certain features in common that distinguish them from others and which explain their choice. First, they are generally closed affairs. Attendance at these festivals is largely restricted to those involved in the television industry and unlike the Oscars, for example, there are no viewing audiences as such. The presentation of awards is not, to our knowledge, broadcast by any television network; and what public awareness of these awards exists is largely due to self-congratulatory press releases issued by national broadcasters advertising their success at a given festival. Consequently, there is no sense in which these awards may pander to an implied audience, because no such audience exists.

Second, these festivals are generally organised by or for those involved in television, rather than organised by third parties. This is most obviously the case with the Prix Italia, which is organised by the Italian public broadcaster Rai. It is less so for the Montreux festival, which was organised in 
order to attract visitors to that part of Switzerland. Thus, although these festivals have different means of generating revenue (through submission or attendance fees), and although the festivals' outlays are small (with no cash prizes), they are not particularly profitable enterprises. Third, these festivals are generally judged by programme makers themselves, rather than (say) noted television critics or television audiences, who may value certain aspects differently depending on their age or situation (Valkenburg and Janssen, 1999; Bartsch, 2012). The Monte Carlo Television Festival is a partial exception to this rule. It has a limited number of Audience Choice Awards, which tend to reward US serial fiction. The remaining festivals typically have small juries of programme makers, occasionally aided by representatives of sponsoring organisations for particular prizes. Fourth, because these festivals award prizes that have no monetary value, there is no sense that broadcasters might trade-off lower expected commercial revenues against expected revenues from prizes. The only incentives generated by these prizes derive from the prestige of the prize or from better export revenues on the world market.

In this combination of characteristics, our television festivals are unlike the Oscars or the Primetime Emmies, but are instead closer to industry awards or best-in-section awards at academic conferences. All three types of awards are the product of a closed meeting, judged by peer review and with few or slight material incentives. The ability of our four television festivals to discriminate between output of varying quality should be similar in degree to the ability of these other gatherings to identify better work. We acknowledge that each of the festivals has distinctive features that themselves might warrant further analysis, but this is not our concern here. We are more interested in what they have in common in what they identify as worthy of prizes, and this is connected to specific creative industry formations.

\subsection{Prix Italia}

The Prix Italia is the oldest of the four festivals considered here, established in 1949 as an international radio festival. The average number of prizes awarded has increased over time (to 
twelve in 2012) due principally to the addition of special sponsored prizes, and prizes for interactive, online, and mixed-media productions. The 2012 festival featured four 'genre' awards (Performing Arts, Music and Arts, Cultural and General Interest, and Current Affairs), two generalist awards (Movies and Mini-series, Series and Serials), two 'technology' prizes (best interactive website linked to a TV and radio programme, Multiscreen award), and one sponsored prize (the Signis award, given for the programme which best contributed "to the promotion of human values"). Prix Italia awards are the least concentrated by country, of all the awards festivals considered here: the effective number of countries in contention is $13.51 .^{1}$ It is also relatively European: $85 \%$ of all awards were won by European production companies.

\subsection{Monte Carlo}

The Monte Carlo television festival is the second oldest of the festivals considered here, and is closest in character to the Prix Italia. It is different in that it often recognizes the contributions of individual actors. Thus, of the fourteen awards given in 2012, eight were for individual actors, two for producers or production teams, and only four for particular programmes. This last category of awards is generic (best television film; best telenovela/soap opera; best comedy TV series; best drama TV series), although earlier editions have featured awards specifically for news and current affairs. A major source of 'genre' awards are a variety of sponsored prizes: the Amade-Unesco prize, the Signis award, and the Monaco Red Cross prize. The Monte Carlo awards are the least European of the four television festivals considered here (European share: $73 \%$ ): the US wins a large share of awards (68 / 420), second only to the UK. A non-negligible proportion of these US awards come from 'audience choice awards', which reward television programmes which are not ordinarily thought of as embodying quality in either of the two aspects discussed above. ${ }^{2}$ The degree of concentration is middling (effective number of countries $=7.3$ ).

That is, the reciprocal of the sum of shares of prizes won by each country squared. 


\subsection{Montreux}

When the Montreux television festival began in 1961, it restricted itself to generic quality awards, with gold, silver and bronze 'roses' awarded to the most meritorious television programmes of that year. ${ }^{3}$ Beginning in 1994, it retained the Rose d'Or, but added a series of genre awards, including, alongside the traditional Arts and Children categories, the only 'game show' awards. Much like the International Emmies, Montreux is dominated by British productions, which took just under half of all the awards over this period $(127$ / 274). As a result, Montreux awards are somewhat concentrated (effective number of countries $=4.17$ ).

\subsection{International Emmies}

The International Emmies have been held continuously since 1979, after an earlier abortive run of awards ceremonies between 1967 and 1969. These Emmies are international in the sense that they are open to non-American television companies only, being awarded to "the best television programs produced, and initially aired, outside the US". The average number of prizes awarded has increased considerably: in 1994, just three prizes were awarded, for Children and Young People, Documentary, and Drama. By 2011, this had increased to ten: two new prizes had been added (best actor, best actress), and a larger number of genre prizes - although these too were rather general categories (TV movie/mini-series, non-scripted entertainment). The majority of prizes awarded at the International Emmies are given to British television companies (83 / 149). As a result, the concentration of prizes by country is marked (effective number of countries $=3.07$ ). Because of this British domination, the International Emmies are the most 'European' of the television festivals considered here: $83 \%$ of awards were won by programmes primarily produced by television companies operating in Europe.

2006 audience choice winners included Desperate Housewives, CSI, and The Bold and the 


\subsection{Summary}

The total number of prizes won over the period 1994 - 2012 by our European subset is shown in Table Error! Reference source not found.. The pairwise correlations between the ranks of countries over this period are interesting: Montreux and the Prix Italia have the highest pairwise correlation (0.69); but generally the correlations between the three European festivals are high, with even the lowest correlation between Monte Carlo and the Prix Italia equal to 0.66. By contrast, the correlation between country ranks at the International Emmies and all other festivals is low, ranging between 0.35 (correlation with Montreux) and 0.58 (correlation with Prix Italia). Much of the explanation for these low correlations seems to lie with countries in the tail end of the distribution of prizes.

\section{Hypotheses}

Here, we discuss four factors that might be thought to affect the quality of television in a particular market, and which therefore might affect the number of prizes won by a particular country, holding other things equal. We also discuss one obvious bias which is present in judging, namely a homecountry bias. Our hypotheses are derived from an economic approach to the operation of creative industries and their markets. We recognise that other approaches, in which the emphasis is on institutional or social factors, might also offer insights into the prize-winning business.

\subsection{Market size}

Market size can be expected to raise prize-winning quality in at least two ways. First, ceteris paribus and with a given level of fixed costs, the larger the market the greater the opportunity to produced specialised programming. Or to put it another way: the more viewers, the more distinct genres we can expect to see produced domestically. This is because, in equilibrium with free entry in the product space, it is the relation between market size and fixed costs that determines the 
number of distinct offerings. Thus in so far as awards target particular programme genres, it becomes more likely as markets grow that there will be programmes specifically oriented to this genre and that there will be competition between programmes within this genre. This benefit from market size will be reinforced over time when there are economies of scope.

Second, there is the possibility that costs of programming are not fixed and that competition takes place in part through the level of fixed costs becoming endogenous to the competitive process. In other words, programme makers need not respond to the opportunity afforded by a larger market through product differentiating in an horizontal manner, they may respond by differentiating vertically: that is, by investing in quality by incurring higher fixed costs (see Shaked and Sutton, 1987 and Sutton, 1991). The more viewers, the more it pays to attract a slice of that market through "must-see" TV. The fabled link between expenditure shares and audience shares are often taken to illustrate this connection between outlays on fixed costs and quality outputs (see David Graham Associates, 2000), and there is some direct evidence that market size can be linked in this way to quality in regional newspaper market (see Berry and Waldfogel, 2010).

We therefore hypothesise that

H1 The larger the domestic market for television in a country, ceteris paribus, the better the quality of television in that country, and the greater the share of prizes won at television awards festivals.

\subsection{Competition}

The links between market size and quality above will generate different observed relationships between the degree of concentration in an industry and the quality of its outputs. The relationship arises in both cases as a by-product of the link between market size and quality rather from the effect of competition per se. Nevertheless, the extent of competition, often captured empirically by the degree of concentration, may itself have effects on quality. For example, competition encourages producers to respond to consumer preferences and to reduce X-inefficiency, or the difference between what firms actually do and what a perfectly profit-maximising firm would do. 
This argument has been deployed in mapping innovation and quality in the music industry ( Peterson and Berger, 1975; Dowd, 2004). Against this, it is sometimes argued that innovation, which is often associated with quality change, is better served by more monopolistic industrial structures (Schumpeter, 1976; Hesmondhalgh, 2007). Thus, its effect is unclear. This informs our second hypothesis.

\section{H2 After controlling for the influence of market size on the level of concentration, concentration affects quality (even if the direction of the effect is an open question).}

\subsection{Pay television}

The market for television is two-sided. Traditionally channels bundle programmes, which are consumed at zero cost by consumers, and adverts, which are paid for by advertisers. As a result, the link between what consumers want and what is supplied is indirect. In this context, the advent of pay-per-view pricing, by directly linking what channels/programmes consumers are willing to pay for to the income received by producers, may encourage better quality programmes in the sense that they respond more directly to consumer tastes. In addition, in practice, the advent of pay-per-view pricing has opened a significant new revenue stream and this may have enabled a growth of programme budgets (the fixed costs of programme making) independently of market size but with similar effects on quality to those sketched above. The extraordinary critical and commercial success of HBO points to these possible effects (Feuer, 2007; Leverette et al, 2008). Consequently,

H3 The greater the percentage of households in a country who pay for television, ceteris paribus, the better the quality of television in that country, and the greater the share of prizes won at television awards festivals.

\subsection{Public Service Broadcasting}

The television market in Europe is significantly affected by the Public Service Broadcasting tradition. Every European television market with the exception of Luxembourg has one or more public broadcasters and there are a range of public service broadcasting requirements placed on 
commercial broadcasters. The amount spent on public service broadcasting - either through a licence fee (a form of hypothecated taxation) or through a general government grant - is considerable, and represents perhaps the most significant cultural intervention by many European states, comparable in magnitude only to the provision of public libraries. As a result, the normal commercial pressures that operate in markets to influence quality which we have discussed above are likely to be significantly mediated by this tradition. For example, the degree of actual commercial competition associated with a particular level of concentration will not be the same when one of the significant broadcasters is publicly owned and is not seeking to maximise profits.

The rationale historically for public provision of broadcasting services has been varied and confusing, comprising reasons related to national defence, protection of nascent industries, a concern over the propaganda potential of emerging mass media, and a desire to foster a sense of national identity. At least one of the purported reasons, however, was to improve the quality of broadcast output with a view to achieving certain desirable ends - entertaining, informing, and educating the populace. Of course, whether public service broadcasting has had this effect is another matter. This is likely to depend on the resources available to the public broadcasters and the acuity with which they are regulated. It does not follow automatically that public service systems produce high quality programmes; resources and regulation may well matter (Lunt and Livingstone, $2012)^{4}$. There is, however, at least one type of programme that has been explicitly identified for public service support and which there are good reasons for supposing would be subject to a market failure: news and current affairs. This is because there are externalities on both the demand and supply side that would lead to underinvestment in these type of programmes if left to commercial market decision making (see Hargreaves Heap, 2005). These considerations inform our next pair of hypotheses. 
H4 The greater the level of public funding for public service broadcasting, ceteris paribus, in a country, the greater the quality of television in that country, and the greater the share of prizes won at television awards festivals.

H5 The type of regulation of public service broadcasting objectives will affect the extent to which public service broadcasting resources promote the objective of quality and hence the share of prizes won at television awards festivals.

\section{5 'Home advantage'}

All of the preceding hypotheses have related characteristics of the market for television in countries to the level of quality of television in that country. Our final hypothesis concerns a factor that could drive a wedge between the quality of television in a country and its share of prizes. We presume that hosting a festival in a country benefits productions from that country. A number of plausible mechanisms suggest themselves: host countries may invest more effort in promoting their productions to the members of the jury; jury members may be disproportionately drawn from the host country and may therefore have a subconscious or conscious bias towards their home country; or jury members (of any nationality) might be subconsciously or consciously biased towards the host country because of a desire to please those who have invited them to serve on the jury. We hypothesise that

H6 Countries hosting a television festival, ceteris paribus, win more prizes at that television festival.

\section{Data and estimation}

For data on the size of the domestic market, we simply take the value of GDP in PPP-adjusted US dollars (Zeileis and Yang, 2012; Heston et al., 2011). Our data on the percentage take up of payper-view television come from successive editions of Thomas and Molony (2008). These publications, together with data from successive editions of European Audiovisual Observatory 
(1994), provide our data on the degree of market concentration, here operationalized as the value of the Herfindahl-Hirschman index based on share of the audience. ${ }^{5}$ Data on public service broadcasting expenditure per head come from successive editions of European Audiovisual Observatory (1994), and are reported in US dollars converting from euros at the current (April 2013) exchange rate. Finally, we represent the home country advantage by using a simple dummy which has a value of one if the relevant country hosted that festival. Summary statistics on these variables are shown in Table Error! Reference source not found.. Note that values for concentration, public broadcasting expenditure, and pay-TV penetration are missing for some of the years in our data. We deal with these missing data by linearly interpolating missing values between known values, and carrying the last known values backwards and forwards for missing points at the ends of our period. All data is normalised before estimation.

Modelling the number of prizes won by different countries at different television festivals poses two technical problems. First, the dependent variable (the number of prizes won by a country) cannot be modelled as a simple count variable, nor as a proportion. Knowing that the United Kingdom won two prizes at a given festival tell us nothing unless we also know whether the total number of prizes awarded that year was four or fourteen. Expressing the dependent variable as a proportion ignores over time variation in the number of prizes awarded: if we know that the United Kingdom wins half of the prizes when only four prizes are awarded, we should be less sure of the quality of television in the United Kingdom than if the United Kingdom had won half of fourteen prizes. Consequently, we must model the dependent variable as a number of successes in a given number of trials.

Second, the process which generates these 'successes' is a competitive one. Consequently, what matters is not the absolute size of the domestic market, but the size of this market compared to the sizes of the other markets which are supplying competitor programmes. Consequently, we must 
model the outcome in a way such that the absolute values of the independent variables do not matter.

To respond to these technical problems, we model the prizes won by each country using a grouped conditional logit model. Let $Y_{i j k}$ be the number of prizes won by country $i$ in year $j$ at festival $k$, for countries $i=1, \ldots, 25$, for years $j=1994 \ldots 2012$, and festivals $k=1, \ldots, 4$. Let $N_{j k}$ be the total number of prizes to be won in a given year $j$ at a given festival $k$. Then the number of prizes won for a given country-festival-year combination can be modelled by using a multinomial distribution with probabilities $p_{i j k}$ :

$Y_{i j k \sim \text { MultpijkNjk }}$

where $i I p_{i j k}$, and where those probabilities are in turn modelled as a combination of variables varying over country-years, a dummy which has a value of one if the festival is being held in that country, and a series of country random-intercepts.

$$
\begin{aligned}
& p_{i j k e x p V i j k i \text { expVijk }} \\
& V_{i j k} \alpha \beta_{1 \text { Domesticmarketsizeij } \beta 2 \text { PayTVhouseholdsij }} \\
& \beta_{3 \text { Marketconcentrationij } \beta 4 P \text { Publicspendonbroadcastingij }} \\
& \beta_{5 \text { Homecountryik } \mu i} \\
& \mu_{i \sim} \quad N \sigma
\end{aligned}
$$

This is equivalent to a conditional logit model with blocks of identical covariates grouped together. ${ }^{6}$

\section{Results}

Table 3 shows the results of our model. Of the four variables which we hypothesised to affect the share of prizes won through improving quality, only two - domestic market size and public broadcasting expenditure (but not PSB regulatory regime) - show statistically significant effects in the predicted direction. The effect of domestic market size is larger than that of public broadcasting 
expenditure - a one standard deviation increase in domestic market size (approx. 700 billion USD) improves the odds of winning a prize by $e^{0.73}=2.08$ times, whereas a standard deviation increase in public broadcasting expenditure only improves the odds by 1.53 times. The coefficients on the two remaining quality-related variables, pay-per-view television and concentration, both have the expected sign, but neither is significantly different from zero. The largest effects in the model come from the dummies related to home country advantage: Switzerland is 2.77 times more likely to win at Montreux than at any other television festival; the advantage for France at Monte Carlo is slightly greater (3.83). Somewhat surprisingly, the Prix Italia is free of home country advantage.

\subsection{Robustness with respect to festival}

These results show our findings when including all data from all four festivals. It is possible, however, that these findings conceal differences between festivals. Are the same factors always significant when examining the results of individual festivals?

Table 4 provides models for each of the four festivals we examine. Of the four variables which we hypothesised to affect the share of prizes won through improving quality, only one - domestic market size - is significant across all four festival models. Public broadcasting expenditure is significant in three of the four models, but is not a significant predictor of prizes at the International Emmies. Conversely, pay television penetration is significant in both the model for the International Emmies, and in the model for the Prix Italia (for which the effect of public broadcasting expenditure was least strong). Neither the effect of concentration nor the PSB regulatory regime was significant in any model. This might suggest that countries which have markets which are in certain respects homologous to the structures in the host country are rewarded. The United States lacks a strong tradition of public broadcasting and derives much of its premium television from the pay-per-view market. Whilst Italy has a long tradition of public broadcasting, the public broadcaster derives a large proportion of its revenue from commercial sources, and is fighting a rearguard action against Sky Italia. 


\subsection{Robustness with respect to country}

In order to test whether our results were driven by the omission or inclusion of one particular country, we ran a series of regressions omitting one country at a time, and recorded the highest and lowest values of the z-values for our coefficients, and the country which was omitted when these maxima and minima were obtained. The results of this delete-one-jackknife are shown in Table 5.

These results show that all of the variables which are significant in the full model are also significant at the $10 \%$ level or above across all the different jack-knife specifications. The effect of domestic market size is strongly significant no matter which country is omitted, but is highest when Germany is omitted. The effect of expenditure on public broadcasting expenditure per head is weakest when the UK is omitted, but even so it remains significant at the $10 \%$ level. One of the variables which was not significant in the full model (pay-TV penetration) reaches significance at the $10 \%$ level when Germany is omitted. This, however, is the only specification in which this variable is significant at this level or above: the average value across all jackknife specifications is 0.1.

\subsection{Other observable implications}

When we argued for a link between expenditure on public broadcasting and the share of prizes won, we did so on the basis that public broadcasters would produce television that had greater quality, and that this would translate into a greater share of prizes. This is one of a number of possible causal interpretations of the correlation between public broadcasting expenditure and success at awards festivals. Another interpretation is that public broadcasting expenditure boosts the revenue of the market as a whole, or reduces competition in the advertising market, or provides a general benchmark for quality, such that the greater success of countries with greater public broadcasting expenditure might also be due to commercial broadcasters in these countries doing better. 
If these alternative interpretations were correct, we would expect that the share of awards going to public broadcasters would be low, and that this share would not be greater in countries with higher expenditure on public broadcasting. Neither of these is the case. The average share of awards won by public broadcasters per country is high, at $87 \%$, and there is a positive but statistically insignificant relationship between this proportion and the average spend on public broadcasting per capita over the entire period $(r=0.096$ on 23 d.f.; $\mathrm{p}=0.647)$.

When we argued for a link between domestic market size and quality, we did so using gross domestic product as a proxy of domestic market size. One alternative interpretation of the link between gross domestic product and the share of prizes won is that gross domestic product, as an indicator of general development, tends to be correlated with many things, and thus that the correlation between gross domestic product and share of prizes does not indicate a correlation between market size and share of prizes. The relationship remains if we use population instead of gross domestic product (see Table 6) - indeed, the effect is slightly stronger. Additionally, there are good reasons to think that a number of countries which under-perform on the basis of their market size are handicapped by the regionalisation of those markets, resulting in a smaller effective market. Inspection of the country random effects show that both Germany and Switzerland perform particularly poorly given their levels of public subsidy and gross domestic product. Both countries are federal systems and have either multiple public broadcasters serving several regional markets (Germany) or a single public broadcaster which operates as a consortium of three linguistically separate organisations (Switzerland).

\section{Out-of-sample prediction test: the US}

We have concentrated on modelling the share of prizes won by European countries in different international television festivals. This is because these festivals are very largely the preserve of European competitors and because many of the concepts and data that we employ are less obviously comparable for countries that do not share Europe's historical orientation towards PSB. It is not 
clear, for example for this and other reasons, how to construct a comparable nation-wide measure of pay-TV penetration or market concentration for the US as a whole.

Fortunately, however, the variables that prove significant in our model (domestic market size and public funding spent on PSB) are readily available for the US and as a result, we can use the experience of the US to perform an out-of-sample prediction test on our model. In particular, to what extent does our model predict the US's share of awards in these different festivals?

For this purpose, we estimated, for European countries only, a reduced form model, using only domestic market size, public funding, and home country indicators as independent variables. We extracted the fixed and random effects from this model. These effects pick up the country specific differences that are not captured by our model. They are normally distributed with a mean approximately equal to zero, and range from under-performance -1.02 (Slovenia) to over performance +1.48 (United Kingdom). For example, it might be argued that the UK overperforms because of the uniqueness of the BBC which is not well captured by our PSB regulatory regime variable. We ran simulations based on this range of values for the US country effect ${ }^{7}$. Had the US under-performed in these terms by as much as the United Kingdom over-performs, then we predict that the USA would win 79 prizes over this period. This compares with the 97 they did in fact win. If instead, we were to suppose that the United States under-performs by as much as Germany underperforms (random effect of -0.67), then we would predict that the USA would win 159 prizes. Had the country effect been neutral, taking a value of zero, our model predicts the US would win 263 prizes.

The performance of the United States is therefore consistent with our model when we assume a US country effect which is an extreme draw from the distribution of country effects estimated for European countries. In other words, while there are reasons for supposing that US performance is driven by the same three key factors as that of European countries, there are other factors that distinguish the US from the typical European country and which tend to detract from 
US success in these festivals. ${ }^{8}$ There is some support therefore for our model from this out-ofsample prediction. But there is also evidence of residual significant differences between the media system of the US and the typical European country of the kind that might be expected by those who emphasise the qualitative difference between the media system of the US and some European countries.

\section{Conclusions}

In this paper, we are concerned with the determinants of success in international television festivals. This is interesting because the quality of programmes matters and success at these festivals is a plausible, if imperfect, indicator of the quality of programming.

We find that countries with larger home markets and with a strong element of public financing of television are more likely to win prizes at these festivals. There are theoretical reasons for believing that both variables contribute to television programmes being deemed worthy of prizes. Consequently, this evidence is consistent with success at these festivals being driven, in part, by structural features of the creative industry. There is also evidence of non-quality considerations playing a role because we find empirical support for a 'home country' bias in these awards. There are a variety of other features of media systems that might plausibly contribute to the quality of programming (like pay-to-view and the form of PSB regulation), but we find no evidence that they affect success at these festivals.

These conclusions are based on the shares of prizes won by European countries in these festivals. We focussed on Europe because it is often argued that the media system in other countries, like the US, are qualitatively different to that of European media systems with their various but strong PSB traditions. To examine the extent of such differences (i.e. also test for the robustness of our model), we perform an out-of-sample prediction test of the model using the US. The model is capable of predicting the success of the US but only with, by European standards, an 
extreme (negative) draw from the range of possible country specific random effects. In other words, there is support for both the model and the proposition that, in addition, the US is notably different in its performance than the typical European country. 


\section{References}

Allen, M. and Lincoln, A. (2004) 'Critical Discourses and the Cultural Consecration of American Films‘, Social Forces, 82(3): 871-894

Bartsch, A. (2012). As Times Goes By: What Changes and What Remains the Same in Entertainment Experience over the Life Span? Journal of Communication, 62:588-608.

Berry, S. and Waldfogel, J. (2010). Product quality and market size. The Journal of Industrial Economics, 58(1): 1-31.

Connolly, S. and Hargreaves Heap, S. (2007). Cross Country Differences in Trust in Television and the Governance of Public Broadcasters. Kyklos, 60 (1): 3-14.

David Graham and Associates (2000), with financial calculations by Chris Goodall, Out of the Box: the programme supply market in the digital age. A report for the Department for Culture Media and Sport.

Dowd, T. (2004). Concentration and Diversity Revisited: Production Logics and the US Mainstream Recording Market, 1940-1990. Social Forces, 82(4): 1411-1455

English, J. F. (2009). The economy of prestige: Prizes, awards, and the circulation of cultural value. Harvard University Press.

European Audiovisual Observatory (1994). Statistical Yearbook. Council of Europe, Strasbourg.

Feuer, J. (2007) 'HBO and the Concept of Quality TV', in J. McCabe, J. and K. Akass (eds) (2007) Quality TV: Contemporary American Television and Beyond, I.B. Tauris, pp. 145-157

Frey, B. (2006). Giving and receiving awards. Perspectives on Psychological Science, 1(4): 377388.

Ginsburgh, V. (2003). Awards, success and aesthetic quality in the arts. The Journal of Economic Perspectives, 17(2): 99-111.

Hallin,D. and Mancini, P. (2004). Comparing Media Systems: Three Models of Media and Politics. Cambridge University Press 
Hallin, D. and Mancini , P. (eds.) (2012). Comparing Media Systems Beyond the Western World. Cambridge University Press.

Hanretty, C. (2012). Public Service Broadcasting's Continued Rude Health. British Academy Policy Centre.

Hargreaves Heap, S. (2005), Television in the digital age: what role for public service broadcasting?. Economic Policy, January: 111-158.

Hesmondhalgh, D. (2007). The Cultural Industries. $2^{\text {nd }}$ edition. Sage. London.

Heston, A., Summers, R., and Aten, B. (2011). Penn World Table Version 7.0. Center for International Comparisons of Production, Income and Prices at the University of Pennsylvania.

Leverette, M., Ott, B.L., and Buckley, C.L. (2008). It's not TV: watching HBO in the post-television era. London: Routledge.

Lunt, P. and Livingstone, S. (2012) Media Regulation: Governance and the Interests of Citizens and Consumers, London: Sage

McCabe, J. and Akass, K. (eds) (2007) Quality TV: Contemporary American Television and Beyond, I.B. Tauris

Médiamétrie, (2012). One TV Year in the World: 2012, or the Multiple TV experience. Press release. Available online at http://www.mediametrie.com/eurodatatv/communiques/one-tvyear-in-the-world-2012-or-the-multiple-tv-experience.php?id=831

Peterson, R. and Berger, D. (1975). Cycles in Symbol Production: The Case of Popular Music. American Sociological Review, 40: 158-173.

Shaked, A. and Sutton, J. (1987). Product differentiation and industrial structure. The Journal of Industrial Economics, XXXVI (2): 131-146.

Schumpeter, J. (1976) Capitalism, Socialism and Democracy, George Allen \& Unwin. London, Sutton, J. (1991). Sunk costs and market structure: Price competition, advertising, and the evolution of concentration. MIT Press.

Thomas, A. and Molony, S. (2008). Western European TV. Informa Telecoms \& Media, London. 
Valkenburg, P., and Janssen, S. (1999) What do children value in entertainment programs? A crosscultural investigation. Journal of Communication, 49:3-21.

Verboord, M. (2012). 'Female bestsellers: A cross-national study of gender inequality and the popular-highbrow culture divide in fiction book production, 1960-2009', European Journal of Communication, 27(4): 395-409.

Verboord, M. (2011). 'Market logic and cultural concentration in French, German and American bestseller lists, 1970-2007', Poetics, 39: 290-315.

Zeileis, A. and Yang, G. (2012). pwt: Penn World Table. R package version 7.0-1. 
Table 1: Prizes by country by festival

\begin{tabular}{lcccc}
\hline Country & Emmies & Monte Carlo & Montreux Prix Italia \\
\hline United Kingdom & 83 & 111 & 127 & 44 \\
France & 7 & 67 & 6 & 27 \\
Germany & 6 & 34 & 24 & 29 \\
Netherlands & 10 & 4 & 14 & 18 \\
Denmark & 5 & 17 & 2 & 19 \\
Sweden & 4 & 11 & 3 & 19 \\
Italy & 0 & 19 & 5 & 11 \\
Spain & 0 & 11 & 8 & 4 \\
Ireland & 0 & 10 & 3 & 5 \\
Switzerland & 0 & 2 & 9 & 6 \\
Norway & 0 & 0 & 5 & 10 \\
Finland & 1 & 2 & 1 & 10 \\
Belgium & 1 & 5 & 3 & 4 \\
Austria & 1 & 2 & 3 & 6 \\
Poland & 1 & 2 & 0 & 8 \\
Croatia & 0 & 0 & 1 & 6 \\
Bulgaria & 0 & 2 & 2 & 0 \\
Portugal & 2 & 2 & 0 & 0 \\
Romania & 2 & 1 & 1 & 0 \\
Slovakia & 1 & 0 & 0 & 2 \\
Czech Republic & 0 & 1 & 0 & 1 \\
Hungary & 0 & 2 & 0 & 0 \\
Lithuania & 0 & 1 & 0 & 0 \\
Serbia & 0 & 0 & 0 & 1 \\
Slovenia & 0 & 0 & 1 & 0 \\
\hline
\end{tabular}


Table 2: Summary statistics

\begin{tabular}{lccccc}
\hline Variable & $\mathbf{N}$ & Mean & Dev. & Min & Max \\
\hline Domestic market (USD millions) & 1850 & 518144.3 & 692515.1 & 25637.94 & 2796577 \\
Pay-TV (percent) & 1776 & 0.491 & 0.251 & 0.04 & 0.99 \\
Concentration (HHI) & 1850 & 2398.604 & 1294.887 & 110.523 & 9530.462 \\
PSB spend (USD per head) & 1702 & 47.363 & 38.433 & 2.25 & 134.029 \\
Home country (Prix Italia) & 1850 & 0.01 & 0.101 & 0 & 1 \\
Home country (Monte Carlo) & 1850 & 0.01 & 0.101 & 0 & 1 \\
Home country (Montreux) & 1850 & 0.01 & 0.098 & 0 & 1 \\
\hline
\end{tabular}


Table 3: Regression results

\begin{tabular}{lcc}
\hline & Prizes (count) & Prizes (count) \\
\hline Domestic market size & $0.731^{* * *}$ & $0.705^{* * *}$ \\
Pay TV & $(0.146)$ & $(0.155)$ \\
& 0.097 & 0.144 \\
Concentration & $(0.156)$ & $(0.164)$ \\
PSB spend & -0.003 & 0.0004 \\
& $(0.084)$ & $(0.084)$ \\
PSB self-regulation & $0.424 * * *$ & $0.318 * *$ \\
& $(0.144)$ & $(0.159)$ \\
PSB regulation by ministry & & 0.701 \\
Home country (Prix Italia) & & $(0.512)$ \\
& & -0.134 \\
Home country (Monte Carlo) & 0.179 & $(0.395)$ \\
& $(0.370)$ & 0.205 \\
& & $(0.371)$ \\
Home country (Montreux) & $1.342^{* * *}$ & $1.357 * * *$ \\
Constant & $(0.214)$ & $(0.214)$ \\
Observations & & $1.065^{* *}$ \\
& $1.017 * *$ & $(0.465)$ \\
& $(0.460)$ & -2.835 \\
& & $(0.663)$ \\
& $-2.726 * * *$ & 1,850 \\
& $(0.604)$ & -1110.56 \\
\hline
\end{tabular}

Notes: $\quad$ Significant at the 1 percent level; $\quad$ Significant at the 5 percent level; Significant at the 10 percent level. 
Table 4: Regression results by festival

\begin{tabular}{|c|c|c|c|c|}
\hline & (1) & (2) & (3) & (4) \\
\hline Domestic market size & $\begin{array}{l}0.989 \\
(0.324)\end{array}$ & $\begin{array}{l}0.851 \\
(0.221)\end{array}$ & $\begin{array}{l}0.968 \\
(0.220)\end{array}$ & $\begin{array}{l}0.731 \\
\quad(0.167)\end{array}$ \\
\hline Pay TV & $\begin{array}{l}0.796 \\
(0.416)\end{array}$ & $\begin{array}{c}0.031 \\
(0.235)\end{array}$ & $\begin{array}{c}0.12 \\
(0.261)\end{array}$ & $\begin{array}{l}0.408 \\
(0.200)\end{array}$ \\
\hline Concentration & $\begin{array}{l}-0.021 \\
(0.291)\end{array}$ & $\begin{array}{l}-0.161 \\
(0.153)\end{array}$ & $\begin{array}{c}0.121 \\
(0.203)\end{array}$ & $\begin{array}{c}0.127 \\
(0.117)\end{array}$ \\
\hline PSB spend & $\begin{array}{l}-0.160 \\
(0.345)\end{array}$ & $\begin{array}{l}0.436 \\
(0.225)\end{array}$ & $\begin{array}{l}0.543 \\
(0.251)\end{array}$ & $\begin{array}{l}0.341 \\
(0.177)\end{array}$ \\
\hline Home country (Monte Carlo) & & $\begin{array}{c}1.648 \\
(1.022)\end{array}$ & & \\
\hline Home country (Montreux) & & & $\begin{array}{c}0.67 \\
(1.102)\end{array}$ & \\
\hline Home country (Prix Italia) & & & & $\begin{array}{c}0.432 \\
(0.868)\end{array}$ \\
\hline \multirow{2}{*}{ Constant } & -3.359 & -1.532 & -2.562 & -1.477 \\
\hline & $(0.699)$ & $(0.371)$ & $(0.515)$ & (0.399) \\
\hline Observations & 450 & 475 & 450 & 475 \\
\hline Log likelihood & -82.926 & -163.904 & -138.818 & -175.114 \\
\hline
\end{tabular}


Table 5: Delete-one-country jack-knife results

\begin{tabular}{lcccc}
\hline Variable & Min. z-value Omitted & \multicolumn{2}{c}{ Max. z-value Omitted } \\
\hline Domestic market size & 4.71 & Norway & 6.43 & Germany \\
Pay TV & 0.12 & Serbia & 1.83 & Germany \\
Concentration & -0.5 & Denmark & 0.31 & Netherlands \\
PSB spend & 1.69 & United Kingdom & 3.56 & Netherlands \\
Home country (Prix Italia) & 5.95 & United Kingdom & 6.4 & Ireland \\
Home country (Monte Carlo) & 1.99 & Germany & 3.13 & United Kingdom \\
Home country (Montreux) & -1.04 & United Kingdom & 0.63 & Sweden \\
\hline
\end{tabular}


Table 6: Regression results, alternate specification

\section{Prizes (count)}

Domestic population

0.836

$(0.167)$

Pay TV

0.123

$(0.159)$

Concentration

$-0.003$

(0.086)

PSB spend

0.516

(0.143)

Home country (Monte Carlo) $\quad 0.158$

(0.370)

Home country (Montreux) $\quad 1.340$

(0.214)

Home country (Prix Italia) $\quad 1.031$

(0.461)

Constant

$-2.937$

(0.605)

Observations

1,850

Log likelihood $-614.607$ 